\title{
Karakteristik berbagai jenis tepung ubi jalar termodifikasi dengan metode autoclaving retrogradation
}

\author{
[Characteristics of various sweet potato flour modified by autoclaving retrogradation \\ method]
}

Sefanadia Putri*, Usdeka Muliani

Poltekkes Tanjungkarang, Jurusan Gizi, Jl Soekarno Hatta No 6 Bandar Lampung, Lampung

* Email korespondensi : sefanadia@poltekkes-tjk.ac.id

Diterima : 08 Juni 2020, Disetujui : 07 Juni 2021, DOI: 10.23960/jtihp.v26i2.83-90

\begin{abstract}
Sweet potato has great potency to be developed as an alternative carbohydrate source in the form of modified sweet potato flour. Autoclaving retrogradation is a physical modification method to improve the physico-chemical characteristics of flour. The purpose of this study was to determine the effect of the autoclaving retrogradation method on the characteristics of various sweet potato flour: dietary fiber, resistant starch, starch digestibility, nutritional content and antioxidant, and to determine the best modified sweet potato flour. The experimental design used a non-factorial completely randomized block design with four replications. The treatment consisted of 6 types of sweet potato, namely control (purple sweet potato without treatment), orange sweet potato, purple sweet potato, honey sweet potato, red sweet potato and purple white sweet potato). The results showed that there were significant differences in dietary fiber, levels of resistant starch, digestibility of starch, nutritional content and antioxidant activity amongs various types of modified sweet potato flour. The best modified sweet potato flour was found in modified red sweet potato flour which contained $44.64 \%$ dietary fiber, $19.75 \%$ resistant starch, $13.50 \%$ starch digestibility, $66.32 \%$ antioxidant activity, with comparable nutritional content .
\end{abstract}

Keywords: Autoclaving retrogradation, physical modification, resistant starch, sweet potato flour

\section{ABSTRAK}

Ubi jalar berpotensi untuk dikembangkan menjadi sumber karbohidrat alternatif dalam bentuk tepung ubi jalar termodifikasi. Autoclaving retrogradation merupakan salah satu metode modifikasi fisik untuk memperbaiki karakteristik fisiko-kimia tepung. Tujuan dari penelitian ini adalah untuk mengetahui pengaruh metode autoclaving retrogradation terhadap karakteristik berbagai jenis tepung ubi jalar termodifikasi : serat pangan, pati resisten, daya cerna pati, kandungan gizi dan aktivitas antioksidan, serta untuk menentukan tepung ubi jalar termodifikasi terbaik. Rancangan penelitian menggunakan rancangan acak kelompok lengkap (RAKL) non faktorial. Perlakuan berupa jenis ubi jalar yang terdiri dari 6 taraf yaitu kontrol (ubi jalar ungu tanpa perlakuan), ubi jalar orange, ubi jalar ungu, ubi jalar madu, ubi jalar merah dan ubi jalar putih ungu dengan empat kali pengulangan. Hasil penelitian menunjukkan bahwa terdapat perbedaan secara nyata serat pangan, kadar pati resisten, daya cerna pati, kandungan gizi serta aktivitas antioksidan pada berbagai jenis tepung ubi jalar termodifikasi. Tepung ubi jalar termodifikasi terbaik terdapat pada tepung ubi jalar jenis merah yang mengandung serat pangan sebesar $44,64 \%$, pati resisten $19,75 \%$ daya cerna pati $13,50 \%$, dan aktivitas antioksidan sebesar $66,32 \%$, dengan kandungan gizi terbaik.

Kata kunci: autoclaving retrogradation, modifikasi fisik, pati resisten, tepung ubi jalar

\section{Pendahuluan}

Indonesia merupakan salah satu negara penghasil ubi jalar. Berdasarkan warna daging umbi, beberapa varietas ubi jalar yang dikenal di Indonesia adalah ubi jalar orange, ungu, madu, merah serta putih ungu. Ubi jalar memiliki potensi sebagai sumber karbohidrat alternatif yang memiliki peluang besar untuk dikembangkan (BeMiller, 2018), misalnya diolah menjadi pangan setengah jadi seperti tepung atau pati. Tepung ubi jalar sebagai bahan baku produk makanan perlu ditingkatkan kualitas fisiologisnya. Hal ini terkait dengan kesadaran masyarakat akan makanan sehat, yang tidak hanya melihat berdasar citarasa dan penampakan menarik saja, namun juga peran fisiologis tertentu yang baik bagi kesehatan tubuh 
Perbaikan kualitas berbagai jenis tepung dapat dilakukan dengan penggunaan enzim dan modifikasi secara asetilasi (Sahnoun et al., 2016), dengan metode heat moisture treatment (HMT) (de Oliveira et al., 2018), serta metode pemanasan dalam pengering drum (Nurdjanah et al., 2017). Modifikasi menggunakan enzim dan asetilasi dapat memperbaiki sifat fisikokimia, reologi serta kandungan gizi tepung tetapi penggunaan bahan kimia mempunyai efek samping terhadap kesehatan tubuh. Perlakuan HMT dan enzimatis dianggap kurang praktis digunakan pada usaha mikro dan home industri (Nurdjanah \& Yuliana, 2019). Modifikasi fisik menggunakan alat pengering berupa drum berputar (rotary dryer) dapat memperbaiki kualitas tepung ubi jalar ungu karena terjadi gelatinisasi sebagian (partly gelatinized) (Nurdjanah et al., 2017), namun alat pengering drum berputar bersifat tradisional dan secara komersil belum beredar di pasaran.

Alternatif perbaikan karakteristik tepung ubi jalar lainnya adalah modifikasi fisik menggunakan metode Autoclaving retrogradation. Metode ini berhasil memperbaiki karakteristik fisikokimia, peningkatan aktivitas antioksidan dan kandungan pati resisten pati beras (Ashwar et al., 2016). Modifikasi pati jagung menggunakan autoclaving retrogradation) menghasilkan restrukturisasi granula pati sehingga terjadi peningkatan kadar pati resisten (Soler et al., 2020). Menurut Zaman \& Sarbini (2016) pati resisten (resistant starch) merupakan salah satu sumber serat pangan yang berfungsi prebiotik. Manfaat positif konsumsi resistant starch (RS) antara lain mencegah sembelit dan flatulensi pada tubuh karena RS dapat mengikat dan menjaga kadarair feses. Konsumsi serat pangan yang direkomendasikan The Indian Council of Medical Research (ICMR) untuk dewasa sebanyak 40 gram perhari sedangkan untuk usia anak sebanyak 15 - 25 gram perhari (Thilagavathi et al., 2020).

Ubi jalar merupakan bahan makanan berpotensi prebiotik karena tingginya jumlah karbohidrat yang dapat difermentasi dalam tubuh (Shen et al., 2018) dan (Guo et al., 2019). Penelitian ini mengkaji pengembangan berbagai jenis tepung ubi jalar termodifikasi menggunakan metode fisik autoclaving retrogradation sehingga memiliki pati resisten yang cukup tinggi sebagai sumber prebiotik. Tujuan penelitian ini adalah untuk mengetahui pengaruh metode autoclaving retrogradation terhadap karakteristik komponen fungsional dan kandungan gizi serta untuk mengetahui karakteristik tepung ubi jalar terbaik.

\section{Bahan dan metode}

\section{Bahan dan alat}

Bahan baku terdiri dari berbagai jenis ubi jalar segar meliputi ubi jalar berkulit putih dengan warna daging ungu, ubi jalar berkulit dan berdaging ungu, ubi jalar kulit dan berdaging merah, ubi jalar kulit dan berdaging orange serta ubi jalar madu yang didapat dari pasar-pasar tradisional Provinsi Lampung. Bahan kimia yang digunakan meliputi : enzim $\alpha$-amilase (merk NOVO) dan enzim amiloglukosidase (merk NOVO), aquades, buffer fosfat, $\mathrm{HCl}, \mathrm{NaOH}$, pepsin, methanol, ethanol, petroleum eter, aceton, alkohol, asam ascorbat, pereaksi dinitrosalisilat (DNS) dan DPPH (Sigma Aldrich) serta bahan kimia lain. Alat-alat yang digunakan meliputi oven drying, autoclave merk SLEVA equitron, freezer merk sharp FRV-200, spektrofotometer, waterbath, sentrifuge, timbangan analitik, dan ayakan ukuran 80 mesh.

\section{Metode penelitian}

Penelitian menggunakan rancangan acak kelompok lengkap (RAKL) non faktorial dengan 4 ulangan. Perlakuan terdiri dari 1 faktor yaitu jenis ubi jalar yang berbeda kulit dan daging umbinya yang meliputi 6 jenis yaitu putih ungu, ungu, merah, orange, madu serta ubi jalar ungu sebagai kontrol tanpa perlakuan modifikasi. Teknik modifikasi yang diterapkan adalah metode fisik autoclaving-retrogradation. Data hasil analisis komponen fungsional yang terdiri dari pati resisten, serat pangan, daya cerna pati, dan aktivitas 
antioksidan, serta kandungan gizi dilakukan analysis of variance (Anova) dan dilanjutkan dengan uji DMRT (Duncan Multiple Range Test) apabila terdapat pengaruh signifikan analisis ragam.

\section{Pelaksanaan penelitian}

Pembuatan tepung ubi jalar termodifikasi meliputi penyortiran dan penimbangan ubi jalar, pengupasan kulit serta pencucian di air mengalir. Umbi ubi jalar bersih dipotong dalam bentuk chip dengan ukuran $3 \mathrm{~mm}$, dilanjutkan dengan autoclaving pada suhu tinggi $\left(121^{\circ} \mathrm{C}, 30\right.$ menit) kemudian didinginkan di suhu ruang dan dilanjutkan penyimpanan pada freezer $\left(4^{\circ} \mathrm{C}, 24 \mathrm{jam}\right)$. Perlakuan pemasakan dan pendinginan dilakukan 3 kali berturut-turut. Chips basah dikeringkan menggunakan oven drying $\left(45^{\circ} \mathrm{C}, 48 \mathrm{jam}\right)$, kemudian digiling menggunakan gilingan tepung dan diayak dengan ayakan alumunium ukuran 80 mesh.

Analisis tepung ubi jalar termodifikasi dan kontrol meliputi komponen fungsional kadar serat pangan (AOAC Official Method 2011.25), daya cerna pati (Anderson et al., 2002), pati resisten (Goñi et al., 1996) yang telah dimodifikasi dan aktivitas antioksidan metode DPPH (Chung et al., 2005), serta kandungan gizi (AOAC, 1995)

\section{Hasil dan pembahasan}

\section{Analisis komponen fungsional}

Komponen fungsional berbagai jenis ubi jalar termodifikasi tersaji pada Tabel 1. Kadar serat pangan berbagai jenis ubi jalar termodifikasi secara umum lebih tinggi dibandingkan kontrol, kecuali tepung ubi jalar jenis madu. Terdapat perbedaan kandungan pati resisten antar tepung ubi jalar, kecuali pati resisten kontrol yang tidak berbeda dengan jenis madu dan orange.

Tabel 1. Analisis komponen fungsional berbagai jenis ubi jalar termodifikasi

\begin{tabular}{|c|c|c|c|c|c|}
\hline $\begin{array}{l}\text { Variabel } \\
\text { (Ubi Jalar) }\end{array}$ & IDF (\%) & SDF (\%) & TDF (\%) & Pati Resisten (\%) & Daya cerna pati (\%) \\
\hline Kontrol & $8,99 \pm 0,56 \quad$ (a) & $2,16 \pm 0,79$ (a) & $11,15 \pm 0,71$ (a) & $5,46 \pm 0,92 \quad$ (a) & $9,75 \pm 0,82 \quad$ (b) \\
\hline Orange & $13,75 \pm 1,54$ (b) & $2,82 \pm 1,1 \quad$ (a) & $16,57 \pm 2,38(b)$ & $4,01 \pm 1,75$ (a) & $10,21 \pm 0,42(b)$ \\
\hline Ungu & $17,04 \pm 0,94$ (c) & $11,54 \pm 3,51$ (c) & $28,58 \pm 3,98(c)$ & $11,69 \pm 2,69$ (c) & $10,37 \pm 0,65(b)$ \\
\hline Madu & $11,10 \pm 0,31$ (a) & $4,03 \pm 0,76(a b)$ & $15,13 \pm 1,79(a b)$ & $4,04 \pm 1,17$ (a) & $6,09 \pm 1,47$ (a) \\
\hline Merah & $25,46 \pm 2,26$ (d) & $19,18 \pm 4,88(d)$ & $44,64 \pm 1,77(d)$ & $19,75 \pm 1,67(d)$ & $13,50 \pm 1,35$ (c) \\
\hline Putih Ungu & $16,29 \pm 2,44$ (c) & $7,73 \pm 2,87(b c)$ & $24,02 \pm 1,69$ (c) & $8,41 \pm 2 \quad$ (b) & $10,11 \pm 0,56(b)$ \\
\hline
\end{tabular}

Angka yang diikuti huruf yang berbeda menunjukkan perbedaan yang nyata menurut uji DMRT 5\%

IDF : Insoluble dietary fiber (serat pangan tidak larut), SDF : Soluble dietary fiber (serat pangan larut)

TDF : Total dietary fiber (total serat pangan)

Tepung ubi jalar merah termodifikasi mengandung total serat pangan (TDF) sebesar 3-4x lipat lebih besar dibandingkan tepung ubi jalar kontrol. Metode autoclaving retrogradation meningkatkan kadar serat pangan tidak larut (IDF) dan serat pangan larut (SDF). Peningkatan serat pangan dapat disebabkan oleh proses perlakuan siklus fisik yaitu pemanasan-pendinginan selama penerapan autoclaving retrogradation. Metode tersebut dilaporkan menghasilkan kandungan serat pangan sedikit lebih baik pada oat bran (Özkaya et al., 2017).

Kadar pati resisten tepung ubi jalar termodifikasi autoclaving retrogradation berkisar antara 4,01 - 19,75 $\%$ (Tabel 1). Tepung ubi jalar ungu yang dimodifikasi metode autoclaving retrogradation mengandung pati resisten 11,69\%, dua kali lipat dibandingkan tepung ubi jalar kontrol. Sementara tepung ubi jalar jenis merah termodifikasi mengandung pati resisten $19,75 \%$, tertinggi diantara sampel tepung ubi jalar. Menurut Setiarto et al. (2015) pati resisten tipe 3 (RS 3) adalah pati yang teretrogradasi melalui reasosiasi ikatan antara amilosa rantai pendek pada unsur hidrogen setelah proses pemanasan menggunakan autoklaf dan langsung dilanjutkan dengan proses pendinginan. Perlakuan pemanasan dan pendinginan 
menyebabkan terbentuknya pati resisten tipe 3 tepung malanga (Espinosa-Solis et al., 2021). Tingginya kandungan pati resisten berhubungan erat dengan tingginya kadar amilosa (Nakamura et al., 2016) dan peningkatan kadar serat pangan larut (Mudgil, 2017). Pernyataan tersebut sejalan dengan hasil penelitian ini, yaitu tepung ubi jalar merah termodifikasi memiliki serat pangan yang sangat tinggi yaitu sebesar 44,64 $\%$. Agustina et al. (2016) menyatakan bahwa proses suhu tinggi dan suhu rendah mengakibatkan tepung ubi jalar modifikasi mudah teretrogradasi sehingga terjadi rekristalisasi yang dapat meningkatkan pembentukan RS-3 sehingga pati resisten menjadi tinggi. Produksi pati meningkat sampai $9 \%$ akibat perlakuan pemanasan metode autoclaving (Sajilata et al., 2006). Gelatinisasi dan retrogradasi merupakan tahapan proses modifikasi yang terjadi pada mekanisme awal proses autoclaving. Suhu autoklaf sebesar $121^{\circ} \mathrm{C}$ dapat membentuk RS3 secara optimum sebagaimana dilaporkan oleh Setiarto et al. (2019).

Tingginya serat pangan pada tepung ubi jalar termodifikasi dapat dijadikan sebagai bahan makanan yang sehat dan unggul (Cruz-Requena et al., 2016). Kandungan serat pangan tertinggi $(44,64 \%)$ terdapat pada tepung ubi jalar merah termodifikasi sehingga berpotensi sebagai sumber serat pangan dan bahan pangan diet. Kandungan 10- $20 \%$ RS akibat degradasi dan retrogradasi dapat digunakan untuk bahan tambahan makanan (BTM) pada susu, biskuit, pasta dan lainnya. Makanan yang mengandung pati resisten tinggi dapat dianggap sebagai makanan fungsional, berfungsi dalam mengontrol glukosa darah dan mencegah penyakit kronis seperti diabetes dan obesitas (Barretti et al., 2020).

Nilai cerna pati berhubungan erat dengan proporsi pati yang diserap oleh enzim-enzim pada pencernaan manusia (Bello-Pereza et al., 2018). Menurut Setiarto et al. (2015) rendahnya daya cerna pati mengindikasikan kadar RS tinggi. Daya cerna pati semua tepung ubi jalar termodifikasi setelah mengalami perlakuan autoclaving retrogradation berkisar antara 6,09-13,50\%, dengan nilai terendah terdapat pada tepung ubi jalar madu termodifikasi dan tertinggi terdapat pada jenis merah. Cahyana \& Wijaya (2017) menyatakan bahwa peningkatan aksesibilitas enzim amilase berpengaruh pada perubahan daya cerna pati. Tepung ubi jalar termodifikasi dengan metode autoclaving-retrogradation yang mengandung pati resisten RS-3 dan rendah daya cerna mengindikasikan bahwa produk pangan ini mempunyai indeks glikemik rendah.

Aktivitas antioksidan tepung ubi jalar termodifikasi mempunyai nilai yang lebih rendah dibandingkan kontrol dan terdapat perberbedaan antar jenis tepung ubi jalar termodifikasi. Nilai aktivitas antioksidan terendah terdapat pada jenis madu dan tertinggi pada kontrol. Kandungan antosianin memegang peranan penting dalam penentuan aktivitas antioksidan. Nurdjanah et al. (2017) dan Nurdjanah \& Yuliana (2019) menyatakan bahwa kandungan pigmen antosianin pada ubi jalar ungu lebih tinggi daripada jenis ubi jalar berdaging orange atau putih.

Tabel 3. Aktivitas antioksidan berbagai jenis ubi jalar termodifikasi

\begin{tabular}{lll}
\hline Variabel & Mean (\%) & SD \\
\hline Kontrol & $83,26(\mathrm{~d})$ & 0,61 \\
Orange & $43,01(\mathrm{ab})$ & 6,03 \\
Ungu & $65,32(\mathrm{c})$ & 5,31 \\
Madu & $39,53(\mathrm{a})$ & 3,61 \\
Merah & $66,32(\mathrm{c})$ & 0,54 \\
Putih Ungu & $47,07(\mathrm{~b})$ & 7,79 \\
\hline
\end{tabular}

Keterangan : Angka yang diikuti huruf yang berbeda menunjukkan perbedaan yang nyata menurut uji DMRT 5\%

Aktivitas antioksidan tepung modifikasi mengalami penurunan dibandingkan dengan kontrol Perlakuan autoclaving retrogradation pada suhu tinggi yang diulang sebanyak 3 kali menyebabkan . komponen asam menguap dan senyawa fenol banyak berkurang, sehingga terjadi penurunan aktivitas antioksidan. Menurut Ruttarattanamongkol et al. (2016) tingginya suhu pemanasan dan adanya reaksi 
oksidasi pada bahan pangan menyebabkan terjadinya penurunan aktivitas antioksidan. Menurut Puspita et al. (2018) kandungan antosianin pada bahan pangan akan hilang akibat proses pemanasan dengan cara penguapan air karena terjadi kontak bahan pangan terhadap uap air tersebut.

\section{Kandungan gizi berbagai jenis tepung ubi jalar termodifikasi}

Hasil analisa kandungan gizi menunjukkan terdapat perbedaan kandungan air, abu, protein, lemak, karbohidrat serta serat kasar antar tepung ubi jalar termodifikasi dan kontrol, keculai pada jenis ungu dan madu (table 2). Kadar air tepung ubi jalar termodifikasi autoclaving-retrogradation pada penelitian ini berkisar antara 3,84-7,01\% dan telah memenuhi persyaratan standar.

Tabel 2.Kandungan gizi berbagai jenis ubi jalar termodifikasi

\begin{tabular}{|c|c|c|c|c|c|c|}
\hline $\begin{array}{l}\text { Variabel } \\
\text { (Ubi Jalar) }\end{array}$ & Air (\%) & Abu (\%) & $\begin{array}{l}\text { Protein } \\
\text { (\%) }\end{array}$ & $\begin{array}{c}\text { Lemak } \\
(\%)\end{array}$ & Serat (\%) & Karbohidrat (\%) \\
\hline Kontrol & $2,43 \pm 0,17$ (a) & $2,19 \pm 0,31$ (a) & $7,44 \pm 0,38(d)$ & $0,39 \pm 0,08$ (a) & $2,42 \pm 0,27$ (c) & $85,23 \pm 3,21$ (b) \\
\hline Orange & $7,01 \pm 0,06(f)$ & $2,74 \pm 0,12(c)$ & $4,02 \pm 0,35(a)$ & $2,92 \pm 0,09(\mathrm{e})$ & $2,04 \pm 0,29$ (b) & $81,29 \pm 0,24$ (a) \\
\hline Ungu & $4,17 \pm 0,01(d)$ & $2,46 \pm 0,04(b)$ & $3,92 \pm 0,06(a)$ & $0,94 \pm 0,03(b)$ & $5,26 \pm 0,23(e)$ & $83,24 \pm 0,17(a b)$ \\
\hline Madu & $4,84 \pm 0,07$ (e) & $2,43 \pm 0,01(b)$ & $5,18 \pm 0,21$ (c) & $2,22 \pm 0,09(d)$ & $1,95 \pm 0,12(b)$ & $83,37 \pm 0,20(a b)$ \\
\hline Merah & $4,01 \pm 0.06(c)$ & $3,61 \pm 0,02(d)$ & $4,79 \pm 0,08(b)$ & $2,15 \pm 0,18(d)$ & $3,26 \pm 0,21(d)$ & $82,18 \pm 0,15(a)$ \\
\hline Putih Ungu & $3,84 \pm 0,03(b)$ & $2,75 \pm 0,06(c)$ & $3,73 \pm 0,11(a)$ & $1,40 \pm 0,38(c)$ & $0,62 \pm 0,14(a)$ & $87,65 \pm 0,61(c)$ \\
\hline
\end{tabular}

Keterangan : Angka yang diikuti huruf yang berbeda menunjukkan perbedaan yang nyata menurut uji DMRT pada taraf alfa 5\%

Kadar air terendah terdapat pada tepung kontrol dan paling tinggi pada jenis orange termodifikasi. Rendahnya kandungan air pada tepung kontrol disebabkan proses pembuatannya tanpa perlakuan autoclaving dan freezing namun langsung dikeringkan sehingga kandungan air tepung ubi jalar tersebut rendah. Fetriyuna et al. (2016) menyatakan bahwa peningkatan sifat pengikatan air pada pati berbanding lurus dengan penambahan tingkat aw pada pati akibat meningkatnya daya serap pengikatan air dalam pati. Tabel 2 menunjukan bahwa kadar air tepung ubi jalar ungu sebesar 2,43\% dan setelah dilakukan proses autoclaving dan freezing meningkat menjadi $4,17 \%$.

Kadar abu tepung termodifikasi autoclaving retrogradation berkisar antara 2,43-3,61\%, dengan kadar abu tertinggi pada ubi jalar jenis merah (3,61\%). Sementara, kadar protein tepung termodifikasi pada penelitian ini berkisar antara 3,73-5,18\%, dengan nilai terendah terdapat pada jenis putih ungu dan semuanya lebih rendah dibandingkan tepung ubi jalar kontrol. Perlakuan pemanasan dengan metode autoclaving menyebabkan terlepasnya ikatan protein terlarut dan merubah sifat protein pada bahan pangan (Chang \& Zhang, 2017). Pemanasan dapat menurunkan kandungan protein akibat terdenaturasinya protein (Naibaho et al., 2009), sehingga tepung tanpa perlakuan pemanasan (control) mengandung kadar protein lebih tinggi. Berdasarkan Tabel Komposisi Pangan Indonesia (2018) standar kadar abu pada tepung ubi jalar maksimal 2,8\%, sedangkan kandungan protein adalah 2,8\%, sehingga kadar protein dan kadar abu pada penelitian ini telah sesuai dengan standar.

Kandungan lemak pada penelitian ini berkisar antara 0,39-2,92\%, sehingga masih sesuai dengan syarat standar Tabel Komposisi Pangan Indonesia (2018). Tepung ubi jalar kontrol mengandung lemak terendah sedangkan tertinggi pada jenis orange. Salah satu ciri tepung yang berasal dari tanaman umbi adalah rendahnya kandungan lemak yang terkandung dalam bahan.

Kadar serat kasar pada penelitian ini berkisar antara 0,62 - 5,26\%., dan total karbohidrat berkisar antara $81,29-87,65 \%$. Nilai terendah didapat pada jenis putih ungu dan tertinggi pada jenis ungu. Nilai terendah total karbohidrat didapat pada jenis orange dan tertinggi pada jenis ungu. Varietas dan umur panen ubi jalar merupakan faktor yang mempengaruhi kandungan karbohidrat tepung ubi jalar (Nurdjanah \& Yuliana, 2019). Kandungan gizi berbagai jenis tanaman ubi jalar yang digunakan dalam penelitian ini 
berpengaruh terhadap total karbohidrat sampel tepung hasil penelitian ini. Berdasarkan Tabel Komposisi Pangan Indonesia (2018) standar kadar karbohidrat pada tepung ubi jalar adalah $84,4 \%$ sehingga semua kadar karbohidrat pada penelitian ini selaras dengan persyaratan standar.

\section{Kesimpulan}

Teknik autoclaving retrogradation menghasilkan perbedaan komponen fungsional (serat pangan, kadar pati resisten, daya cerna pati, kandungan gizi (air, abu, protein, lemak, serat kasar, karbohidrat) dan juga aktivitas antioksidan berbagai jenis tepung ubi jalar termodifikasi. Tepung ubi jalar termodifikasi terbaik terdapat pada tepung ubi jalar jenis merah dengan kandungan serat pangan sebesar 44,64\%, pati resisten $19,75 \%$ daya cerna pati $13,50 \%$, aktivitas antioksidan $66,32 \%$, serta kandungan gizi yang meliputi kadar air 4,01 \%, kadar abu 4,01 \%, kadar protein 4,79 \%, kadar lemak 2,15\%, kadar serat kasar 3,26 \%, karbohidrat total $82,18 \%$.

\section{Ucapan terima kasih}

Penulis mengucapkan terimakasih kepada Poltekkes Tanjungkarang Kementerian Kesehatan Republik Indonesia atas dana yang diberikan untuk melakukan penelitian ini melalui skema Penelitian Terapan Unggulan Perguruan Tinggi (PTUPT) Tahun 2019.

\section{Daftar pustaka}

Agustina, Faridah, D. N., \& Jenie, B. S. L. (2016). Pengaruh retrogradasi dan perlakuan kelembaban panas terhadap kadar pati resisten tipe lii Daluga. Jurnal Teknologi Dan Industri Pangan, 27(1), 78-86. https://doi.org/10.6066/jtip.2016.27.1.78

Anderson, A. K., Guraya, H. S., James, C., \& Salvaggio, L. (2002). Digestibility and pasting properties of rice starch heat-moisture treated at the melting temperature (Tm). Starch/Starke, 54(9), 401-409. https://doi.org/10.1002/1521-379X(200209)54:9<401::AID-STAR401>3.0.CO;2-Z

AOAC. (1995). Official Method of Analysis of Association of Official Analytical Chemist (14 th). AOAC inc.

AOAC International. (2012). AOAC official method 2011.25 insoluble, soluble, and total dietary fiber in foods. AOAC International. http://www.matsutani.com/productsframeset.html, https://www.megazyme.com/docs/default-source/scientific-publications/37b-insoluble-solubleand-total-dietary-fiber-in-foods.pdf?sfvrsn=2

Ashwar, B. A., Gani, A., Wani, I. A., Shah, A., Masoodi, F. A., \& Saxena, D. C. (2016). Production of resistant starch from rice by dual autoclaving-retrogradation treatment: Invitro digestibility, thermal and structural characterization. Food Hydrocolloids, 56, 108-117. https://doi.org/10.1016/j.foodhyd.2015.12.004

Barretti, B. R. V., Almeida, V. S. de, Ito, V. C., Silva, B. M., Carvalho Filho, M. A. da S., Sydney, E. B., Demiate, I. M., \& Lacerda, L. G. (2020). Combination of organic acids and heat-moisture treatment on the normal and waxy corn starch: thermal, structural, pasting properties, and digestibility investigation. Food Science and Technology, 2061, 1-7. https://doi.org/10.1590/fst.33120

Bello-Pereza, L. A., Flores-Silvab, P. C., Agama-Acevedoa, E., \& Tovar, J. (2018). Starch digestibility: Past, present, and future. Journal of the SCience of Food and Agriculture. https://doi.org/https://doi.org/10.1002/jsfa.8955

BeMiller, J. (2018). Carbohydrate Chemistry for Food Scientists 3rd Edition (Third edit). Elsevier Ltd. https://www.elsevier.com/books/carbohydrate-chemistry-for-food-scientists/bemiller/978-0-12812069-9

Cahyana, Y., \& Wijaya, E. (2017). Pengaruh heat moisture treatment ( HMT ) terhadap kandungan pati tercerna lambat. Jurnal Penelitian Pangan (Indonesian Journal of Food Research), 2(1), 33-37.

Chang, S. K. C., \& Zhang, Y. (2017). Protein Analysis. Food Analysis, 213-226. https://doi.org/10.1007/978-3319-45776-5

Chung, Y. C., Chen, S. J., Hsu, C. K., Chang, C. T., \& Chou, S. T. (2005). Studies on the antioxidative activity of Graptopetalum paraguayense E. Walther. Food Chemistry, 91(3), 419-424. https://doi.org/10.1016/j.foodchem.2004.06.022 
Cruz-Requena, M., Aguilar-González, C. N., Prado-Barragan, L. A., Carneiro-da Cunha, M. das G., dos Santos Correia, M. T., Contreras-Esquivel, J. C., \& Rodríguez-Herrera, R. (2016). Dietary fiber: An ingredient against obesity. Emirates Journal of Food and Agriculture, 28(8), 522-530. https://doi.org/10.9755/ejfa.2015-07-521

de Oliveira, C. S., Bet, C. D., Bisinella, R. Z. B., Waiga, L. H., Colman, T. A. D., \& Schnitzler, E. (2018). Heatmoisture treatment (HMT) on blends from potato starch (PS) and sweet potato starch (SPS). Journal of Thermal Analysis and Calorimetry, 133(3), 1491-1498. https://doi.org/10.1007/s10973-018-7196-9

Espinosa-Solis, V., Zamudio-Flores, P. B., Espino-Díaz, M., Vela-Gutiérrez, G., Rendón-Villalobos, J. R., Hernández-González, M., Hernández-Centeno, F., López-De la Peña, H. Y., Salgado-Delgado, R., \& Ortega-Ortega, A. (2021). Physicochemical characterization of resistant starch type-iii (Rs3) obtained by autoclaving malanga (xanthosoma sagittifolium) flour and corn starch. Molecules, 26(13), 1-13. https://doi.org/10.3390/molecules26134006

Fetriyuna, Marsetio, \& Pratiwi, R. L. (2016). Pengaruh lama modifikasi heat-moisture treatment (HMT) terhadap sifat fungsional dan sifat amilografi pati talas Banten (Xanthosoma undipes K. Koch). Jurnal Penelitian Pangan (Indonesian Journal of Food Research), 1(1), 44-50. https://doi.org/10.24198/jp2.2016.vol1.1.08

Goñi, I., García-Diz, L., Mañas, E., \& Saura-Calixto, F. (1996). Analysis of resistant starch: A method for foods and food products. Food Chemistry, 56(4), 445-449. https://doi.org/10.1016/0308-8146(95)00222-7

Guo, Z., Zhao, B., Li, H., Miao, S., \& Zheng, B. (2019). Optimization of ultrasound-microwave synergistic extraction of prebiotic oligosaccharides from sweet potatoes (Ipomoea batatas L.). Innovative Food Science and Emerging Technologies, 54(December 2018), 51-63. https://doi.org/10.1016/j.ifset.2019.03.009

Mudgil, D. (2017). The Interaction between insoluble and soluble fiber. In Dietary Fiber for the Prevention of Cardiovascular Disease: Fiber's Interaction between Gut Micoflora, Sugar Metabolism, Weight Control and Cardiovascular Health. Elsevier Inc. https://doi.org/10.1016/B978-0-12-805130-6.00003-3

Naibaho, N. M., Syahrumsyah, H., \& Suprapto, H. (2009). Studi waktu dan metode blanching terhadap sifat fisiko- kimia tepung talas Belitung (Xanthosoma sagittifolium). Jurnal Teknologi Pertanian Universitas Mulawarman, 4(2), 69-74.

Nakamura, S., Katsura, J., Kato, K., \& Ohtsubo, K. (2016). Development of formulae for estimating amylose content and resistant starch content based on the pasting properties measured by RVA of Japonica polished rice and starch. Bioscience, Biotechnology and Biochemistry, 80(2), 329-340. https://doi.org/10.1080/09168451.2015.1088373

Nurdjanah, S., \& Yuliana, N. (2019). Teknologi Produksi dan Karakteristik Tepung Ubi Jalar Ungu Termodifikasi. AURA (Anugrah Utama Raharja). Bandar Lampung.

Nurdjanah, S., Yuliana, N., Astuti, S., Hernanto, J., \& Zukryandry. (2017). Physico chemical, antioxidant and pasting properties of pre-heated purples sweet potato flour. Journal of Food and Nutrition Sciences, 5(4), 140. https://doi.org/10.11648/j.jfns.20170504.11

Özkaya, H., Özkaya, B., Duman, B., \& Turksoy, S. (2017). Effect of dephytinization by fermentation and hydrothermal autoclaving treatments on the antioxidant activity, dietary fiber, and phenolic content of oat bran. Journal of Agricultural and Food Chemistry, 65(28), 5713-5719. https://doi.org/10.1021/acs.jafc.7b01698

Pratiwi, M., Faridah, D. N., \& Lioe, H. N. (2018). Structural changes to starch after acid hydrolysis, debranching, autoclaving-cooling cycles, and heat moisture treatment (HMT): A review. Starch/Staerke, 70(1-2). https://doi.org/10.1002/star.201700028

Puspita, L., Pardede, S., Rusmarilin, H., \& Yusraini, E. (2018). Uji aktivitas antioksidan pada perbandingan ekstrak buncis ( $P$ Haseolus Vulgaris $L$.) ekstrak dan daun pandan wangi (Pandanus Amaryllifolius Roxb ) menggunakan metode Frap (Ferric Reducing Antioxidant Power). 6(3), 457-462.

Ruttarattanamongkol, K., Chittrakorn, S., Weerawatanakorn, M., \& Dangpium, N. (2016). Effect of drying conditions on properties, pigments and antioxidant activity retentions of pretreated orange and purple-fleshed sweet potato flours. Journal of Food Science and Technology, 53(4), 1811-1822. https://doi.org/10.1007/s13197-015-2086-7

Sahnoun, M., Ismail, N., \& Kammoun, R. (2016). Enzymatically hydrolysed, acetylated and dually modified corn starch: physico-chemical, rheological and nutritional properties and effects on cake quality. Journal of Food Science and Technology, 53(1), 481-490. https://doi.org/10.1007/s13197-015-1984-z 
Sajilata, M. G., Singhal, R. S., \& Kulkarni, P. R. (2006). Resistant Starch?A Review. Comprehensive Reviews in Food Science and Food Safety, 5(1), 1-17. https://doi.org/10.1111/j.1541-4337.2006.tb00076.x

Setiarto, R. H. B., Amalia, L., Febriani, Y., Fitrilia, T., \& Widhyastuti, N. (2019). Pengaruh Siklus Pemanasan Bertekanan-Pendinginan terhadap Komposisi Kimia dan Kualitas Biologi Tepung Campolay (Pouteria campheciana). Jurnal Riset Teknologi Industri, 13(1), 54. https://doi.org/10.26578/jrti.v13i1.4985

Setiarto, R. H. B., Jenie, B. S. L., Faridah, D. N., \& Saskiawan, I. (2015). Study of Development Resistant Starch Contained in Food Ingredients as Prebiotic Source. Jurnal Ilmu Pertanian Indonesia, 20(3), 191-200. https://doi.org/10.18343/jipi.20.3.191

Shen, Y., Sun, H., Zeng, H., Prinyawiwatukul, W., Xu, W., \& Xu, Z. (2018). Increases in phenolic, fatty acid, and phytosterol contents and anticancer activities of sweet potato after fermentation by Lactobacillus acidophilus. Journal of Agricultural and Food Chemistry, 66(11), 2735-2741. https://doi.org/10.1021/acs.jafc.7b05414

Soler, A., Velazquez, G., Velazquez-Castillo, R., Morales-Sanchez, E., Osorio-Diaz, P., \& Mendez-Montealvo, G. (2020). Retrogradation of autoclaved corn starches: Effect of water content on the resistant starch formation and structure. Carbohydrate Research, 497(June), 108137. https://doi.org/10.1016/j.carres.2020.108137

Tabel Komposisi Pangan Indonesia. (2018). Tabel Komposisi Pangan Indonesia. Kementerian Kesehatan Republik Indonesia. https://panganku.org/id-ID/beranda

Thilagavathi, T., M. Pandiyan, M., Suganyadevi, M., Sivaji, M., Yuvaraj, M., \& Sasmitha, R. (2020). Dietary fibre -health benefits. Journal of Chemical Information and Modeling, 2(6), 519-522.

Zaman, S. A., \& Sarbini, S. R. (2016). The potential of resistant starch as a prebiotic. Critical Reviews in Biotechnology, 36(3), 578-584. https://doi.org/10.3109/07388551.2014.993590 